\title{
ON THE DISCOURSE OF THEOLOGY AS A MEDICAL SCIENCE IN THE CONTEXT OF CARITATIVE SOCIAL WORK
}

\author{
Skaidrīte Gūtmane \\ Latvian Christian Academy (Latvia)
}

\begin{abstract}
Social work theory and practice today follow a concept born in mid-19th century industrialised society; however, it is not the sole concept. Even since the fourth century, an alternative concept of caritative social work (CSW) has been known, and it is currently embedded in the European Social work model. The article shows the therapeutic potential of the concept of CSW based on the JudaeoChristian model, which is based on the revelation of Biblical and patristic anthropology elaborated since the first decades of the Christian era (mainly in Alexandria and Antioch, ancient centres of learning). Today, with the Covid-19 crisis, and with European society undergoing traumatic experiences, described as alienation, unemployment, depression, etc, the therapeutic potential of CSW should be recalled by social work professionals. The therapeutic potential of CSW is revealed through an interdisciplinary approach. Patristic anthropology is an interdisciplinary approach showing ways to encourage human social activity, encompassing both personal and societal perspectives. The concept of deification provided by Judeo-Christian anthropology touches the ontological structure of man, and is described as a method for the proper conceptualisation of the complexity of the client's problem, without ignoring its spiritual aspects. The potential of CSW is helpful for people in a society who are at risk to recover from setbacks.

KEY WORDS: Church Fathers, patristic anthropology, caritative social work, client as personality, therapeutic potential.
\end{abstract}

\begin{abstract}
Anotacija
Socialinio darbo teorija ir praktika šiandien vadovaujasi XIX amžiaus vidurio industrinėje visuomenejje gimusia koncepcija, kuri nèra vienintelè. Jau nuo IV amžiaus žinota alternatyvi karitatyvinio socialinio darbo (KSD) samprata, kuri šiuo metu įtraukta ị Europos socialinio darbo modelį. Straipsnyje atskleidžiamos KSD koncepcijos terapinès galimybès, pagrisstos judèjų ir krikščionių socialinio mokymo modeliu ir Biblijos bei patristinès antropologijos prieigomis, kurios žinotos jau pirmaisiais krikščioniškosios eros dešimtmečiais (daugiausia Aleksandrijoje ir Antiochijoje, senovès mokymosi centruose). Šiandien, Europos visuomenei patiriant traumuojančią Covid-19 patirtį, kuri pasireiškia kaip žmonių susvetimejjimas, nedarbas, depresija ir pan., socialinio darbo specialistams būtina sutelkti terapinị KSD potencialą, pasitelkus tarpdisciplininį požiūrị. Patristinè antropologija, kaip tarpdisciplininė prieiga, atskleidžia žmogaus socialinę veiklą skatinančias galimybes tiek asmeniniame, tiek visuomeniniame kontekste. Sudievinimo koncepcija, pateikiama judejjų krikščioniškosios antropologijos teiginiuose, atskleidžia ontologinę žmogaus struktūrą, konceptualizuojant kliento sudètingumo problemą, tai gali būti tinkama veikimo prieiga. KSD gali padèti rizikos situacijoje esantiems žmonèms susigrąžinti savo jègas.
\end{abstract}

PAGRINDINIAI ŽODŽIAI: Bažnyčios tėvai, patristinė antropologija, karitatyvinis socialinis darbas, klientas kaip asmenybė, terapinis potencialas.

DOI: http://dx.doi.org/10.15181/tbb.v87i2.2322 


\section{Introduction}

The therapeutic potential of the concept of CSW, based on the Judaeo-Christian model, is in turn based on the revelation of Biblical and patristic anthropology elaborated since the first decades of the Christian era (mainly in Alexandria and Antioch, ancient centres of learning). Today, with the Covid-19 crisis, and European society undergoing traumatic experiences, described as alienation, unemployment, depression, etc, the therapeutic potential of CSW should be recalled by social work professionals. The therapeutic potential of CSW is revealed through an interdisciplinary approach.

The method of CSW is best revealed through an interdisciplinary and holistic approach to man both as a client and as a personality, where the social sciences, social work theory, patristic anthropology and theology meet.

Caritative social work is based on the Judaeo-Christian revelation about man in his relationship to God. Many believe that this is a teaching close to religion. However, human logic alone has been found unable to reveal the truth of Christian charity. Where human logic has remained beyond competence, its logic was revealed by the Word of God, the revelation of God in Christ, especially in the New Testament, and in the anthropological and theological teachings of the Church Fathers.

\section{Scientific and practical relevance}

Christianity should not be treated as 'just another religion', at least not in the sense that the term 'religion' is often misused today, where God 'lives in Heaven' as a demanding and punishing Being, Who abandoned people on this sinful Earth to suffer pain and crises. Whereas the gap between the Creator and the creature is insurmountable, it is not a fatal destiny, neither from a human perspective nor from God's perspective. The well-known Russian theologian Alexey Osipov describes the essence of Christianity as follows: 'The essence of Christianity is included in one name: Christ. What does it mean? It is the sacrifice that Christ made for man. He took upon himself all nature of man, all our corruption, all deformity that came upon Adam, and then upon all his descendants, because they fell away from God. Christ became a sin for us (2 Cor. 5: 21). This is the essence that distinguishes Christianity from all other religions' (Osipov, 2021).

This explanation of the essence of Christianity is important for the anthropological approach based on the Judaeo-Christian revelation. The incarnation of Christ, the Second Person (Greek Hypostasis) of the Trinity, in theological language, is

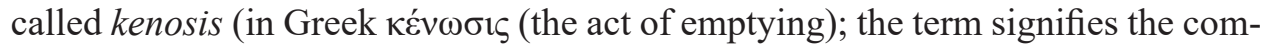
plete emptying of God, His perfect obedience to the will of the Father, and giving 
up His own will. The Christian doctrine of salvation also calls for such 'emptying' of men. Of course, man is unable to attain God-likeness; however, without renouncing selfishness, greed, lust and sin, man cannot be blessed by God, which is a contradiction (e.g. Luke 11:24-26). Without ascetic submission to Christ, man remains in the grip of selfishness, which blocks salvatory redemption of God in Christ. Consequently, it causes the suffering both of himself and members of his family, and man becomes capable of anti-social actions, and finally comes into conflict with his own nature.

The Church shows the way to the deification of man by following Christ. To

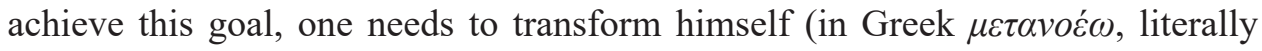
'rearrangement of thinking', 'repentance'). It is a process of purification through repentance or confession, which is described as an act of synergy between man and God. This is the only way to heal a person from the pathologies of his soul and body, and to regain his personal identity 'in God's image and likeness'. The purification and transformation of the self outside the Church is an illusion: Christianity has always been person-oriented.

Christianity as a science of healing (or therapy) of the human soul and subsequent positive social activity was developed during the patristic age (the second to seventh centuries). It is not an accident that in the Christian East, people who lived like 'therapists' and showed the way to others were called 'theologians'. Theology, the true knowledge of God (we call it Dogmatics), was interconnected with practical life, and the knowledge was produced by those who experienced healing from crisis. Their experience testifies to the value of the method to approach the client's complexity without ignoring its spiritual aspects (Ларше, 2016; 2018). Here, I will mention some findings by several important theologians arguing the importance of theology in working with man. The Church Fathers emphasised that theology as pure speculation without practical asceticism is fictitious, and cannot provide therapeutic effect.

Of course, CSW is not about theology. However, theological knowledge integrated into a holistic approach to the human spirit, soul and body will benefit for bettering social performance. ${ }^{1}$ Biblical and patristic anthropology differ from anthropology as a social science, which deals mainly with the physical and social characteristics of man in comparative contexts. Competence in theology equips one with discernment beyond the reach of purely psychological methods.

St Gregory of Naziansus (329-390, Cappadocia, awarded the title of 'theologian' by the Orthodox Church), who was venerated as a saint in both the Western

See, e.g.: Немесий Эмесский. (1994). О природе человека. Москва; Григорий Нисский, св. (1995). Об устроении человека. Санкт-Петербург; Theologie de l'homme. Essais d'anthropologie orthodoxe. (1973). Contacts (Paris), Vol. 25, № 84; Хоружий, С. С. (1998). Аналитический словарь исихастской антропологии. К феноменологии аскезы. Москва. 


\section{Skaidrīte Gūtmane}

and the Eastern churches, claims that no one can speak of God, since they who 'crawl on earth' are not qualified to do this, and 'theology is revealed to those who have purified their souls and bodies'. Only a person who masters the Jesus Prayer ('Lord Jesus Christ, Son of God, have mercy upon me, a sinner'), and has at least reached the first stage of the Ladder of Divine Ascent, is regarded as a beginner in theology. Only by practising the Jesus Prayer can one know God: 'You are a theologian if you really pray. If you pray, you are a theologian' (Добротолюбие [Philokalia], 2004, p. 182).

One of the key authors of Christian asceticism, St John the Ladder (579-649, Sinai), the author of the well-known ascetic treatise 'The Ladder of Divine Ascent', describes the making of true theology in a harsh manner typical of the Desert Fathers (early monks, in the fourth to seventh centuries): 'If a person has not been able to submit his feelings to God and has not started to learn from God, it is hard to speak of God. If this connection with God has not taken place, it is difficult to talk about God [...] He who has not known God personally chatters about Him by intuition' (Jānis Pakāpnieks, 2014, XXX, p. 21, 23). Today, we would say that 'theology' without an objective basis leads people astray in delusion (in Greek aí $\rho \delta \sigma \varsigma$, 'personal opinion'). The result of such a judgment of God is 'demonic theology', and leads to deviant social behaviour. A heart which is not cleansed by the Spirit of God 'can only communicate what he learns from the unclean spirit and his passions. Those who live guided by passion cannot touch theology' (Jānis Pakāpnieks, 2014, XXVII). The connection between 'outward man' and 'inner man' is obvious.

The same idea was developed by the Late Church Father, monk and philosopher St Gregory Palamas (p. 1296-1357/9, Greece): the one without experience or knowledge 'goes the path of his judgment, and tries to explain with his intellect what is beyond its competence. Such a person has obviously gone to the edge of insanity.' St Maximus the Confessor (b. 662, Byzantine Empire) calls these views 'primitive' (Добротолюбие [Philokalia], 2004, p. 182-188); whereas the true theologian is one who has experience of 'the theology written by the Spirit in his acts and deeds'. This understanding of theology closely tied to personal spiritual growth is firmly rooted in the Christian Scriptures. This is how therapeutic potential is revealed: it works for social correction, and connects the potential with the ontological foundation of manhood. For example, St Paul wrote: 'To one the Spirit gives the word of wisdom, to another the word of knowledge' (1 Cor. 12: 8). So theology is a science which arranges the results of spiritual experience in the world of social affairs and communication between people, but the 'talk of wisdom' in our context would be the ability of CSW to deal with the client, considering his or her spiritual world as one that affects social and mental performance. This definition corresponds with the validation of the interdisciplinary approach 
in CSW, when it comes to the conceptual basis for practice. The therapeutic potential of theology and the corresponding anthropology is an important resource. 'The task of the Church,' writes the contemporary Greek theologian Metropolitan Hierotheos Vlahos, 'is to strive to cure disease, first of all, diseases of the soul that torture people. This is the basis of the New Testament and the teaching of the Church Fathers' (Иерофей [Влахос], 2004). ${ }^{2}$

According to the tradition of the Scriptures followed by the Church Fathers, healing comes from the healed soul. Only a purified person is qualified to grasp the meaning of why Revelation of God in Christ is linked to anthropology. CSW professionals should first change their ways before they aspire to heal others: or at least there should be an intention to do this. This is also true about CSW dealing with the person in difficulties.

From this perspective, theological competence could be used as a tool for the effective struggle for bettering the social and spiritual performance of the client. Speaking ironically, social work without competence in theology is compared to an army general who is ignorant of the art of war, or a butcher who thinks he is a surgeon. A 'specialist' of this kind does not identify either a healthy frame or indications of the true causes of illness. The professional activity of the caritative social worker is similar to that of a medical doctor, due to his involvement in warfare active in both pathologies of the body and the soul, and is aimed at the client's health in the widest sense of the word.

\section{Historical approach of client (What is the client?)}

What is the client? The answer is neither easy nor simple. Some used to say that a client is a person who suffers from a lack of resources, or undergoes a crisis in his personal and societal life. Consequently, the way you treat the client depends on how precisely you put the question. The German philosopher M. Heidegger (1889-1976) once said that 'man asks questions and always has asked questions, just because he himself is a question. Every man and his life is a MYSTERY.'Therefore, let us ask again: what is the client? Let me ask more precisely: what is the client as a personality? What does it mean to offer help to another man? What is the ultimate goal of my professional duties as a social worker? Paradox: a questionnaire conducted by students at the Latvian Christian Academy (2019) shows social workers typically replacing those anthropologically focused questions by others,

\footnotetext{
There are many sources, to mention a few: Hierotheos, Metropolitan of Nafpaktos (1994). Orthodox Psychotherapy: The Science of the Fathers. [Greece:] Birth of the Theotokos Monastery; also several works by the well-known French patrologist and philosopher Jean-Claude Larchet on the healing of psychic diseases (e.g., Larchet, J.-C. (2005). Mental Disorders \& Spiritual Healing: Teachings from the Early Christians. New York: Angelico Press / Sophia Perennis).
} 


\section{Skaidrīte Gūtmane}

namely: 'What's going on in our country?' 'What's going on in a social service institution?' etc. Obviously, these questions move an anthropological problem into the field of sociology, alienated from the client's personality.

Every person goes through changes, and spiritually he steps over the limits of his limited time and space, and reaches eternity. God created the human personality for progressive spiritual movement. In the process, he gets to know his personal calling, inviting him to participate in His Divine Nature. As St Basil the Great put it: 'Man is a creature with the calling to become Divine.' Should social work professionals need to care for this in their work with clients? Of course!

Since the most ancient times, it has been known that men are creatures in need of attention from other people and from God. With this in mind, one should approach the other man's crisis with respect. The Jewish philosopher M. Buber, in the preface to his fundamental work 'The Problem of Man' (Buber, 2000), says that an Orthodox Hassidic rabbi is right: 'I wanted to write a book called "Adam", where I would say everything about man. However, I thought it over, and came to the conclusion that man should be approached with more respect. I can't say anything meaningful about man. This is because man is not visible, he is not transparent and subject to research. Man is a mystery of love. Therefore, man could be described only in his relationship with God. Without a knowledge of God, you don't know either your husband, your wife, your own children, your colleague, or your client.' Therefore, I agree with the German philosopher M. Scheler (1874-1828). When thinking about man and the caring professions, he wrote: 'Human science and the so-called social professions which deal with the explanation and analysis of man, seemingly obscure the human essence rather than reveal it.'

One of the first authors who recognised the mystery of God in man was the Church Father St Gregory of Nyssa (ca. 335-ca. 395, Cappadocia): 'God is a mystery to us, and we cannot grasp it. We humans are created in God's image. An image contains characteristics of the archetype or original. It means: if there is a difficulty to encompass God with human reasoning, consequently also no one can understand and inquire human personality created in God's image' (Azkoul, 1995). Every person is a manifestation of the Eternal God. Consequently, no explanation of the client's personality or his life situation is complete without the oikonomia or Divine household. If a man loses his Divine foundation and Divine calling, he is at risk of losing his humanness. One who rejects the existence of God also rejects respect for the human personality, even if he claims the opposite. No man is autonomous and self-sufficient; neither is he an isolated being, since the essence of the personality is not contained within himself. 'The whole personality of Adam before the Fall was hidden in the Word [...] The Word which dwells within him, makes him a personality. It is his main creative force,' says the great Serbian Or- 
ON THE DISCOURSE OF THEOLOGY AS A MEDICAL SCIENCE IN THE CONTEXT...

thodox theologian of the 20th century St Justin Popovich, an analyst of the 'Spiritual Talks' by St Macarius the Great (Попович, 2004).

The revelation of the Scriptures says every human being is a being with a dual nature. The authors of patristic anthropology were right when they said man should be seen as a direction. On one hand, he is the 'man of the earth', whom God formed 'from the dust of the ground, and breathed into his nostrils the breath of life; and the man became a living being' (Gen 2: 7). On the other hand, man was created by God in His image and likeness (in Hebrew neshāmā, Gen 1:27). To translate it into the language of anthropology, God created man with an infinite anthropological boundary ('His likeness'). If a person lives only as a 'natural being' (V. Lossky), his anthropological boundary is narrowed; and the sense of his or her self-worth is also limited.

Caritative social work claims that every personality is better understood by:

1. Evaluating the proportions of the changing and sustainable parts of the given personality;

2. Recognising both ethical principles and tasks which are seen as important to the given client.

This means that man is naturally made alive with the 'breath of life' (in Hebrew nephesh), a soul that God has given to every living creature, to every bird in the air, etc. V. Lossky says that God has given man 'the possibility of a human soul, i.e. with the potential of God-likeness (in Hebrew neshamā). For hundreds of years, patristic anthropology has described this possibility or direction as deification (in Greek theosis). It is the ability to inherit qualities inherent in God by His nature and essence. Thanks to this, people are able to overcome difficulties and crises in life. The Creator allows man to enter the circle of His uncreated energies and to unleash resources. The process was described by St Gregory Palamas: 'One can deny God. One can deny and forget about one's immortal soul [...] and it is the death of the soul that is the death of the personality in the fullest sense.' St Gregory wrote that it was difficult for him to understand how a person can be an atheist: 'If we compare the human soul with the soul of an animal, I see that animals have only the activity of life, and the soul dies with the flesh.' But the human soul is not comparable to the activities of life. Man is not a social animal. 'Man is comparable only to infinite immortality. By breaking away from God, he kills his soul. The soul is spiritually ugly and evil.'

The death of the soul also affects the forces of life. St Gregory writes that sickness, decay, and the death of the body are the consequences of processes in the spiritual realm to which one deliberately or unconsciously submits oneself with choices of free will. Death and crises are not the punishment of God, but apostasy, 


\section{Skaidrīte Gūtmane}

caused by the illusion of human self-sufficiency, from life processes that are provided by theosis, or deification.

The first to fall away from God and gain death as an eternal consistency was Diabolos (Greek for 'father of lies'). He dragged people into lying and dying. God warned man: 'You will certainly die' (Gen 2: 17), so the days of your life will turn into fatigue, anxiety about life caused by depressed moods; you will experience that the greatest lies are lies with your life, to live seventy, eighty years and not inherit God-likeness, true godliness! Death is the fruit of self-sufficiency, and entered the world when man reduced his neshama, the possibility of godliness, to nephesh, the soul of the animal.

Deification, theosis, as the goal of human life, proves that every human being is a personality, an elite being in the best sense of the word. Man himself is the highest elite, because he carries with him God-likeness, the possibility of deification, to regain the purpose that God has put into every human being by creating life. This is the basic task of free will: to obey the call of divinity (God-likeness), to perfect the image of God in oneself, to develop the mind.

Of course, man has the opportunity to ignore God's call, to reduce the will of his Creator to zero; but then 'his existence loses all meaning because it is no longer the existence of man but of a social animal.' This is exactly what happened to the first man, Adam, who obeyed the spirit of darkness. He lost the divine radiance of God's blessing in which he was clothed, and destroyed the God-likeness. In other words, sin and passion distracted Adam from communication with God, and deprived him of his spiritual life. Man lost the power of light, because the Spirit is the source of strength in man, including his body. There is life in God Himself, and those who are with God gain another strength, the strength of God-likeness. 'Man's renunciation of God-likeness as a task of life is death,' writes St Gregory Palamas. St Isaac the Syrian (613-700, Syria) emphasises in his anthropological texts that 'It is really impossible for man to reach the limit in his path of God-likeness,' because no man has ever attained perfection, because the Wisdom of God has no end: it leads higher and higher, until it connects with God. The unleashing of wisdom in man is a sign of this path, for Wisdom is God himself.

Instead of conclusion. What, then, is the secret of a person or a client? The key to this secret is the human meta-problem. 'Meta' in Greek means a person's need to focus on what is above his mundane nature or overarching goal in the anthropological sense. I agree with that. The contemporary philosopher M. Marmardashvili once said: 'It is a person's choice out of the self-sufficiency of his illusions in the direction of God. He chooses himself, to be a Man.'

The humanity of the human being starts to decay when a person no longer wants to wake it up. The 'death of God' (as Nietzsche said), the death of man as we 


\section{ON THE DISCOURSE OF THEOLOGY AS A MEDICAL SCIENCE IN THE CONTEXT...}

know him, and the despair caused by crises, are stages in one chain. The first step in the direction of God-likeness, or deification, is to turn away from wrong choices and to seek a new life in the Image and likeness of God.

\section{References}

Buber, M. (2000). Das Problem des Menschen. Gütersloh: Gütersloher Verlagshaus.

Hierotheos, Metropolitan of Nafpaktos. (1994). Orthodox Psychotherapy: The Science of the Fathers. [Greece:] Birth of the Theotokos Monastery.

Pakāpnieks, J. sv. (2014). Pakāpieni uz Debesīm. Jūrmala: Latvijas Kristīgā akadēmija.

Larchet, J.-C. (2005). Mental Disorders \& Spiritual Healing: Teachings from the Early Christian. New York: Angelico Press / Sophia Perennis.

Azkoul, M. (1995). St. Gregory of Nyssa and the Tradition of the Fathers. Lewiston. NY: E. Mellen Press.

Theologie de l'homme. Essais d'anthropologie orthodoxe. (1973). Contacts (Paris), Vol. 25 (84).

Григорий Нисский, св. (1995). Об устроении человека. Санкт-Петербург.

Добротолюбие [Philokalia]. (2004). Москва: АНО «Развитие духовности, культуры и науки», Т. 1, с. 182.

Добротолюбие [Philokalia]. (2004). Москва: АНО «Развитие духовности, культуры и науки», Т. 3, с. 182-188. Иерофей (Влахос), митр. (2004). Православная психотерапия. Святоотеческий курс врачевания души. Москва: Свято-Троицкая Сергиева Лавра.

Ларше, Ж. К. (2016). Болезнь в свете православного вероучения. Москва: Сретенский мон.

Ларше, Ж. К. (2018). Исиеление духовных болезней. Москва: Сергиев Посад.

Немесий Эмесский. (1994). О природе человека. Москва.

Осипов, А. И. (2021). В чем сущңность христианства. Available on line: https://lib.pravmir.ru/library/ readbook/1209\#part_10984

Попович, Иустин, прп. (2004). Проблема личности и познания по учению святого Макария Великого. Собрание творений преподобного Иустина (Поповича), Т. 1. Москва: Паломник, с. 235-309.

Хоружий, С. С. (1998). Аналитический словарь исихастской антропологии. In С. С. Хоружий. К феноменологии аскезы. Москва.

Skaidrite Gūtmane - professor, doctor of Humanities (Philology), Rector of the Latvian Christian Academy.

E-mail: rektore@kra.lv 